\title{
Service Branding: A Perspective of Value Co-Creation Orientation
}

\author{
Tianze Li, Haiying Wei \\ Department of Marketing, Management School, Jinan University, Guangzhou, China \\ Email: jeremylee1216@126.com
}

How to cite this paper: Li, T.Z. and Wei, H.Y. (2018) Service Branding: A Perspective of Value Co-Creation Orientation. Journal of Service Science and Management, 11, 256-266. https://doi.org/10.4236/jssm.2018.112018

Received: March 9, 2018

Accepted: April 25, 2018

Published: April 28, 2018

Copyright $\odot 2018$ by authors and Scientific Research Publishing Inc. This work is licensed under the Creative Commons Attribution International License (CC BY 4.0).

http://creativecommons.org/licenses/by/4.0/

\begin{abstract}
This paper gives a general thinking for service branding through the perspective of value co-creation orientation. Firstly, the paper reviews the background of service branding from service marketing and product brand. And then the paper discusses the process of service branding in ways of different models. The perspective of value co-creation orientation comes from S-D logic. Based on the changing from goods dominant logic to S-D logic, service branding process has been changed into different parts. We have a further discussion on this perspective and give some further research directions in order to enrich this area.
\end{abstract}

\section{Keywords}

Service Branding, S-D Logic, Value Co-Creation, Brand Building

\section{Introduction}

Nowadays, brands play an indispensable role in marketing strategy and are increasingly regarded as valuable assets and sources of differentiation, especially for service companies. So far, a number of theoretical frameworks have been proposed to understand how consumers think and respond regarding to brand image. However, these frameworks tend to conceptualize branded physical goods, with little emphasis on service brands [1]. While some models are considered to be applicable to goods and service brands, the potential application of these models to services may be challenged on the grounds that the marketing principles of goods and services are inherently different. In addressing these differences, Berry proposed a service-branding model based on an analysis of existing mature brands, but so far this has not been validated by consumer positions [2]. Based on current growing trend of service brands, this paper is obviously insufficient for academic research to the academic attention to service 
brand, and discusses the scale of service branding under the view of value co-creation orientation. In the following paper, we would discuss the background and the process of the service branding first, and then examine service branding from the value co-creation orientation perspective.

\section{The Background of Service Branding}

\subsection{Service Marketing}

Service marketing forms the overall framework of service branding, including internal marketing, external marketing and interactive marketing. In addition to the traditional $4 \mathrm{p}$ (products, prices, locations and promotions), the service marketing portfolio includes 3 more P's: process, physical evidence, and people. Kotler Service Marketing Framework can also be used as the cut-in point of brand building. A company promises to serve its products to its customers through external marketing. Frontline employees are committed to provide customer service and create service experience by interactive marketing. Resources and processes enable companies and employees to achieve and promote their service commitments in internal marketing [3].

Due to the intangible nature of service, it is important for service companies to tell customers who they are and emphasizes on striking the balance between business and the level of service branding. Customers often use the company's brand name as an agent, making choices in different products and may be willing to pay premium prices on this basis. As a result, efficient service organizational systems are regarded as part of the branding process.

\subsection{Service Branding}

The service characteristics make service brand different from product brand. Many scholars have investigated the differences between them from the brand association, brand communication, consumer brand awareness and brand management and other aspects.

From Brand Association, the elements of service brand association are more complex than product brand. Keller believes that Product brand association includes product related factors (such as product core functions, product quality, etc.) as well as non-product factors (such as price, packaging, audience image,

etc.) two major categories. Product brand is ultimately a concrete product as solid support, and service brand is the tangible embodiment of intangible services, it covers the associative elements which are more complex. O'Cass and Grace Proposed Service brand association including brand name, service price, service environment, core services, employee image, Word-of-mouth and so on [4]. From this, we can see that service brands should not only take into account the intangible services themselves, but also consider the provision of services, front-line staff, consumers and many other stakeholders in order to maintain consistent. Thus, the association of Service brands is more complex, service brand management is more difficult. 
The effective way of brand communication is also an issue to be discussed for scholars. Compared to product brand, the service brand has more communication contact points than the product brand. In addition to the basic marketing activities, service brand associates with service environment, employee image, core services and etc. They are the service provider and accept the main body of communication important contact point. Moreover, their task is to ensure effective brand communication have been made. At the same time, De Chernatony found that, since consumers cannot evaluate the service quality in advance, it is highly important to transfer the early stage communication to future commitment [5]. This commitment will translate into a consumer's expectation to service. And by the consumer subjective factors, based on consumer subjective factors excessive brand communication and very few brand communications are not conducive to service brand building, so how to grasp the degree of brand communication is also a difficult job, the consistency of brand communication plays a decisive role in product brand communication management.

From the perspective of consumer brand perception, since the process of production to consumption is a relatively long process, and consumer's perception of the product brand can be reflected on product before purchase, and on other processes afterward [6]. The intangibility of service makes customers not consume the service brand before their perceptions to this brand. And this will affect their judgment to the service brand. In addition, service providers are company's front-line staff; their personal image and service quality can be decisive to consumers' decision as well as subjective feelings. Moreover, service environment and other factors will have a rather comprehensive impact on the general service quality. Thus, consumers' brand perception will be subject to a variety of factors constraints.

In terms of brand management, product managers are usually responsible to product brands, mainly included some basic product marketing activities. McDonald, De Chernatony and Harris pointed out that the service brand should implement the company's brand strategy, the company's senior brand management, while integrating marketing and human resources departments to implement the overall brand strategy [7]. This requires service brand to manage not only the basic marketing activities, but also staff effective management. Recruitment is an important way for company to identity employees that share the united value, which will be crucial to make company keep consistent.

Based on the differences between the service brand and the product brand, there would be some solutions should be carried out so that companies could manage different type of branding separately. Basically, service branding consists of all the activities of brand building in different service sectors, service industries, and service enterprises [8]. Berry has pointed out that for the tangible goods, product is the main brand. However, in terms of intangible service, the enterprise is the main brand. Service enterprise branding is the developing trend of the service brand construction [2]. Therefore, this part mainly serves as the 
prophase basic work, refines the service Enterprise brand concept model, proposes the Service Enterprise brand concept dimension, and carries out the certain examination, provides the foundation for the follow-up discussion service brand construction.

\section{The Ways of Service Branding}

How to build a successful service brand? For this important issue, few scholars have put forward some theoretical models, the empirical research remains blank. Berry did the preliminary research of 14 well performance service enterprise in USA, and put forward a service brand model, which enabled the enterprises cultivate service brand assets through brand meaning and brand consciousness [2]. The brand meaning mainly originates from the customer experience, while the brand consciousness mainly originates from the brand of the enterprise display. In addition, enterprises cannot control the word-of-mouth and external publicity, which will also affect the brand meaning and brand awareness. Meanwhile, De Chernatony, Drury and Segal-horn explored the process of service branding through in-depth interviews with 28 experts from leading consulting firms in the UK's brand, advertising, design, marketing/management, market research areas, and proposed a star model [5]. The model shows that successful service brands tend to be born of organizations with balanced internal and external orientation. Santos-Vijande et al. suggested from the perspective of corporate internal management brand, the empirical discovery of Brand Management System (BMS), including three dimensions, which are brand-orientation, internal branding and strategic brand management [9]. This can help enterprises create and maintain a strong brand, effective to help enterprises better performance.

These studies are essential from the perspective of the internal management brand of service enterprises and regard the service enterprises as the leading providers of service branding. In the perspective of value co-creation, companies place the service branding in the social network and ecological environment, pay attention to its process interaction with themselves, employees, customers, stakeholders in the dynamic ecological environment of mutual interaction to create brand value. Therefore, this paper will focus on the internal mechanism of brand-oriented service enterprises, and discuss the mutual influence in the brand value and the key influence of the leader. Who are the key stakeholders in the service branding process? What are the main dimensions of the activity that the brand value co-creates? How do these values create common activities that affect customer perceptions and ultimately service branding? What are the boundary conditions for co-creating value? Through the answer of the above questions, we should figure out the main path model of service branding for those service companies.

\section{The Model of Service Branding}

Research on the theoretical model of product brand has been more mature, such 
as Brand Recognition Model, Brand Recognition Six Prism Model and so on. However, scholars have set up service brand research theory models to enrich this service area. This paper selected the following models to review.

\subsection{Service Branding Asset Model}

Berry constructs a service branding asset model, that puts forward that service branding assets mainly come from brand cognition and brand connotation, in which brand cognition has indirect influence on service brand assets, and brand connotation has direct influence, from the perspective of consumers [2].

Brand cognition refers to the extent to which the service brand can be recognized and remembered by consumers, which is controlled by the direct influence of the enterprise brand display. Through basic marketing activities, enterprises show the basic elements of their brand association, so as to show their service ability to consumers. In addition, brand awareness is also influenced by external brand communication, which is not controllable. The external brand communication mainly includes the Word-of-mouth and the public relations, the consumer's information transmission as well as the consumer and the enterprise's relation will have the certain influence on the service enterprise brand cognition.

Brand connotation refers to the consumer's perception of the brand. The customer experience is the direct influence factor. The consumer's experience of a service directly affects its understanding of the brand connotation of the enterprise. In addition, the external brand communication will also have a certain indirect impact on the brand connotation. Therefore, the brand connotation is more consumer's subjective feeling, this kind of feeling compared to the more objective brand cognition to the service brand assets influence to be bigger.

\subsection{Service Branding Management Model}

De Chernatony and Segal suggested the service branding management model and they conducted in-depth interviews around the service brands of 28 senior consultants in London for branding and advertising, aiming to explore the driving factors of successful service branding. Based on the literature review, the model was constructed according to these driving factors [5].

The model is a circle, that the enterprise first determines the corporate culture, so as to determine the brand commitment to customers, through external communication to the customer, while internal communication, through the training of employees to confirm its service values and corporate culture consistent, so as to ensure the consistency of service brand contact. Customers through the company's external communication and their own front-line staff to provide services to the actual experience of this brand transfer consistency evaluation, thus forming a brand image, in order to maintain customer relations, and ultimately make customers identify with corporate culture, to achieve long-term trust relationship.

This model puts forward a set of service brand management scheme from the 
perspective of enterprise, and the scheme is a complete circulatory system, which can be used for reference by enterprises. But because the interview object is the senior consultant of various professions, neither the front-line staff nor the consumers, the scientific study of the specific elements of service brand needs to be further validated.

\subsection{Service Branding Verdict Model}

Grace and O' Cass suggested the service brand verdict model based on the analysis of the consumer branding equity model of Keller [10] and the necessary service brand elements, after the analysis of data validation. The model convinces that consumer brand association and brand communication have an impact on customer satisfaction, and brand communication will also have a certain effect on its association. In addition, the consumer's attitude to the brand comes from the customer's satisfaction, and indirectly from the consumer's brand association and brand Communication. This brand attitude, whether positive or negative, will ultimately affect the brand's judgment.

Based on the qualitative research, the model is more scientific than the brand equity model of Berry by using real data of consumers. However, this model lacks the representativeness because the model only selects the random customer group of some Australian sub-services. The data cannot be applied to the service industry except the investigated so that the general applicability of the model needs further discussion.

These three models of service branding are the most classic model in this area. However, these models could not follow the marketing trend based on the shared economy. Service brand need to be as a planform to create value from different stakeholders. Thus, scholars need to focus on the view of value co-creation to model service branding.

\section{The View of Value Co-Creation Orientation}

\subsection{Value Co-Creation and Service Branding}

The concept of Value Co-Creation was first introduced into the marketing field by Prahalad and Ramaswamy, who believed that the rules of the 21st century market were changing [11]. In addition to the price system that traditionally regulates supply-demand relationships, there is also an interaction and a large degree of cooperation between consumers and service providers. Moreover, co-creation can provide benefits for businesses and consumers, such as increased consumption and use of experience and stimulation of product and service innovation [12]. Vargo and Lusch suggested that the mode of marketing thinking should shift from Good-dominant Logic to service-dominant Logic, and the basic proposition of this logic is value co-creation [13]. Thus, the interests (activities and services) could be produced only when the collaboration and interaction of the stakeholders come out [14]. They further pointed out that value co-creation is inherent in the service companies, as market offerings are essen- 
tially generated when services are contacted.

The value co-creation provides a new view for us to investigate service branding. In the perspective of value co-creation, there are three main evolution of enterprise branding. Firstly, brand value is created together in the ecosystem of stakeholders; Secondly, stakeholders form social networks rather than simple relationships between customers and brands; Last but not least, brand value is created dynamically through social interaction among different stakeholders [15] [16].

Value co-creation has become a new logical starting point for understanding service branding. However, the emerging research ideas just remain in theoretical deduction, case study and general brand management. There is still a lack of clear theoretical framework, operational key structure and deterministic empirical research conclusions. In particular, there is a lack of research into the process of creating brand value through interaction among customers, brands, and other stakeholders [17]. Based above all, the research should start from the construction of service enterprise branding, probes into the intrinsic mechanism and path of service branding, and then probes into the relationship among key stakeholders in the process of service brand cultivation. What's more, it is really urgent to figure out what are the main dimensions of their brand value together creating activities and how these value co-creating activities affect customer cognition or enhance the value of service branding experience.

\subsection{Co-Creation Orientation}

Service has specific experiential attributes and contextual attributes [18]. Following this logic, service branding is just adhering to the experience and context of service-dominant logic. Therefore, the enterprise's co-creative orientation will affect the process of service branding. The enterprise value co-creation guidance is a kind of enterprise organization level construction and the service enterprise whole to the value altogether creates the guiding belief and the culture, belongs to the service enterprise market direction [19]. According to the theory of value co-creation, the basic idea of this orientation is to benefit from the whole service ecosystem. Under the guidance of the high enterprise, the value of service branding may produce "zelizer circuits", extend to consumer's brand consumption situation, and finally enlarge the brand value perceived by consumers.

In addition, value co-creation is not limited to service enterprises and consumers. There is also value co-creation between enterprises and employees (brand internalization), employees and consumers (interactive marketing), enterprises and other stakeholders (upstream and downstream networks), and stakeholders are resource integrator, working together in an interdependent ecosystem [20].

\section{Conclusions}

First of all, customer value delivery needs to come from the cooperation between 
the enterprise and the customer. It is absolutely necessary to guide the customers to participate in the effective value co-creation [21]. In addition, the findings show that in the three dimensions of the value co-creation, the common problem-solving has the most obvious driving effect on the customer's cognitive value, which shows that it is often difficult to predict problems in the process of providing the knowledge-intensive industry service which is mainly characterized by uncertainty, customization and complexity. More flexible and effective problem response and resolution than the programming and implementation aspects of the program will enhance customer awareness of service value. Therefore, in particular, enterprises need to establish a rapid response mechanism for customer problems.

Moreover, it has shown that the interaction of resources and value co-creation at the behavioral level ultimately depends on the guidance of service enterprise's service-dominant logic [22]. This new way of thinking reflects and criticizes the traditional visual angle of value co-creation and believes that the value comes from the service experience of enterprises and customers in the interaction [23]. The essence of supplier marketing activities is to provide value proposition. Only customer is the judge of value in service interaction. The enterprises with higher logic identity will tend to create value through resource integration and relationship interaction. Therefore, in order to ensure the continuous institutionalization of enterprise resource interaction and value co-creation, enterprise executives should consciously learn the theory of service-dominant logic and the value co-creation orientation as important directions and ways of thinking of action, and through demonstration, staff training, salary system and the formal system of enterprises to infiltrate and implement the service enterprises.

\section{Limitations and Further Research}

\subsection{Limitations}

This paper reviews all parts around service branding in the perspective of value co-creation orientation, but there are still some limitations. Firstly, we just suggest that scholars should explore more models to follow the new marketing trend but give no quantitative suggestions on it. For one hand, we are investigating the effects of value co-creation orientation on the evaluations of service branding through some experiments and further research would be updating. For another hand, we would have more discussions on the importance of quantitative model on service branding. What's more, this paper does not review the relevant area of service branding and we do hope scholars could figure out more directions related to the core of service branding.

\subsection{Further Research}

Based on the limitations, this paper hopes the further research will focus on the main two areas, which are service brand internationalization and brand informatization bases on big data. 
At present, the service enterprise internationalization speed is more and faster [24], the service brand internationalization gradually becomes the forefront trend for service branding [25]. On the basis of analyzing that how to build service brand through value co-creation and how to promote service branding through brand innovation, the internationalization of service branding and the internationalization of service enterprises are closely related to the international division of labor, as well as the main influence of the internationalization of the service industry, and the internationalized process of services branding. Therefore, it is necessary to discuss the internationalization expansion of service branding, to figure out how the different types of service enterprises choose different modes to enter the international market and how to optimize the internationalization strategy of service branding under the background of the current cross-border E-commerce companies.

In the information age, with the application of Internet and the development of information technology, brand information management has become the supporting platform of service branding [26]. In the perspective of value co-creation, service branding is the dynamic creation of different stakeholders through social interaction [15] [16], focusing on the process of cooperation and openness involving enterprises and users. Therefore, it is necessary to rely on brand information management technology to achieve consumer relationship management, to create a multi-party participation technology platform and so on [27] [28].

\section{Acknowledgements}

The authors gratefully acknowledge financial support from the National Natural Science Foundation of China (NSFC) (No. 71772077) and the Fundamental Research Funds for the Central Universities (No. 15JNLH005).

\section{References}

[1] Turley, L.W. and Moore, P.A. (1995) Brand Name Strategies in the Service Sector. Journal of Consumer Marketing, 12, 42-50. https://doi.org/10.1108/07363769510095298

[2] Berry, L.L. (2000) Cultivating Service Brand Equity. Journal of the Academy of Marketing Science, 28, 128-137. https://doi.org/10.1177/0092070300281012

[3] Bao, S., Toivonen, M. and Mikkola, M. (2012) Service Branding in International Markets. In Management of Technology (ISMOT), 2012 International Symposium, 87-91. https://doi.org/10.1109/ISMOT.2012.6679434

[4] O'Cass, A. and Grace, D. (2003) An Exploratory Perspective of Service Brand Associations. Journal of Services Marketing, 17, 452-475. https://doi.org/10.1108/08876040310486267

[5] De Chernatony, L. and Segal-Horn, S. (2003) The Criteria for Successful Services Brands. European Journal of Marketing, 37, 1095-1118. https://doi.org/10.1108/03090560310477681

[6] Kervyn, N., Fiske, S.T. and Malone, C. (2012) Brands as Intentional Agents Framework: How Perceived Intentions and Ability Can Map Brand Perception. Journal of 
Consumer Psychology, 22, 166-176. https://doi.org/10.1016/j.jcps.2011.09.006

[7] McDonald, M.H., De Chernatony, L. and Harris, F. (2001) Corporate Marketing and Service Brands-Moving beyond the Fast-Moving Consumer Goods Model. European Journal of Marketing, 35, 335-352. https://doi.org/10.1108/03090560110382057

[8] Grönroos, C. (2007) Service Management and Marketing: Customer Management in Service Competition. John Wiley \&Sons, Hoboken, New Jersey.

[9] Santos-Vijande, M.L., del Río-Lanza, A.B., Suárez-Álvarez, L. and Díaz-Martín, A.M. (2013) The Brand Management System and Service Firm Competitiveness. Journal of Business Research, 66, 148-157. https://doi.org/10.1016/j.jbusres.2012.07.007

[10] Grace, D. and O’Cass, A. (2005) Service Branding: Consumer Verdicts on Service Brands. Journal of Retailing and Consumer Services, 12, 125-139. https://doi.org/10.1016/j.jretconser.2004.05.002

[11] Prahalad, C.K. and Ramaswamy, V. (2000) Co-Opting Customer Competence. Harvard Business Review, 78, 79-90.

[12] Bitner, M.J., Ostrom, A.L. and Morgan, F.N. (2008) Service Blueprinting: A Practical Technique for Service Innovation. California Management Review, 50, 66-94. https://doi.org/10.2307/41166446

[13] Vargo, S.L. and Lusch, R.F. (2004) Evolving to a New Dominant Logic for Marketing. Journal of Marketing, 68, 1-17. https://doi.org/10.1509/jmkg.68.1.1.24036

[14] FitzPatrick, M., Varey, R.J., Grönroos, C. and Davey, J. (2015) Relationality in the Service Logic of Value Creation. Journal of Services Marketing, 29, 463-471. https://doi.org/10.1108/JSM-01-2015-0038

[15] Gummesson, E., Kuusela, H. and Närvänen, E. (2014) Reinventing Marketing Strategy by Recasting Supplier/Customer Roles. Journal of Service Management, 25, 228-240. https://doi.org/10.1108/JOSM-01-2014-0031

[16] Merz, M.A., He, Y. and Vargo, S.L. (2009) The Evolving Brand Logic: A Service-Dominant Logic Perspective. Journal of the Academy of Marketing Science, 37, 328-344. https://doi.org/10.1007/s11747-009-0143-3

[17] Payne, A., Storbacka, K., Frow, P. and Knox, S. (2009) Co-Creating Brands: Diagnosing and Designing the Relationship Experience. Journal of Business Research, 62, 379-389. https://doi.org/10.1016/j.jbusres.2008.05.013

[18] Vargo, S.L. and Lusch, R.F. (2016) Institutions and Axioms: An Extension and Update of Service-Dominant Logic. Journal of the Academy of Marketing Science, 44, 5-23. https://doi.org/10.1007/s11747-015-0456-3

[19] Pera, R., Occhiocupo, N. and Clarke, J. (2016) Motives and Resources for Value Co-Creation in a Multi-Stakeholder Ecosystem: A Managerial Perspective. Journal of Business Research, 69, 4033-4041. https://doi.org/10.1016/j.jbusres.2016.03.047

[20] Vargo, S.L. and Morgan, F.W. (2005) Services in Society and Academic Thought: An Historical Analysis. Journal of Macromarketing, 25, 42-53. https://doi.org/10.1177/0276146705275294

[21] Polese, F., Mele, C. and Gummesson, E. (2017) Value Co-Creation as a Complex Adaptive Process. Journal of Service Theory and Practice, 27, 926-929. https://doi.org/10.1108/JSTP-07-2017-0111

[22] Wilden, R., Akaka, M.A., Karpen, I.O. and Hohberger, J. (2017) The Evolution and Prospects of Service-Dominant Logic: An Investigation of Past, Present, and Future Research. Journal of Service Research, 20, 345-361. 
https://doi.org/10.1177/1094670517715121

[23] Sorensen, A. and Drennan, J. (2017) Understanding Value-Creating Practices in Social Media-Based Brand Communities. The Service Industries Journal, 37, 986-1007. https://doi.org/10.1080/02642069.2017.1373098

[24] Javalgi, R.R.G. and Todd, P.R. (2011) Entrepreneurial Orientation, Management Commitment, and Human Capital: The Internationalization of SMEs in India. Journal of Business Research, 64, 1004-1010. https://doi.org/10.1016/j.jbusres.2010.11.024

[25] Upadhyayula, R.S., Dhandapani, K. and Karna, A. (2017) The Role of Cluster Presence and Quality Certification in Internationalization and Performance of Offshore Service Providers. Journal of International Management, 23, 72-86. https://doi.org/10.1016/j.intman.2016.11.004

[26] Wuepper, D. and Patry, M. (2017) The World Heritage List: Which Sites Promote the Brand? A Big Data Spatial Econometrics Approach. Journal of Cultural Economics, 41, 1-21. https://doi.org/10.1007/s10824-016-9266-9

[27] Alavi, S., Ahuja, V. and Medury, Y. (2012) Metcalfe's Law and Operational, Analytical and Collaborative CRM-Using Online Business Communities for Co-Creation. Journal of Targeting, Measurement and Analysis for Marketing, 20, 35-45. https://doi.org/10.1057/jt.2012.3

[28] Westergren, U.H. (2011) Opening up Innovation: The Impact of Contextual Factors on the Co-Creation of IT-Enabled Value Adding Services within the Manufacturing Industry. Information Systems and e-Business Management, 9, 223-245. https://doi.org/10.1007/s10257-010-0144-2 